\title{
KEPUASAN MASYARAKAT TERHADAP PELAYANAN PUBLIK DI KABUPATEN PURBALINGGA
}

\section{Zaula Rizqi Atika1*, Shadu Satwika Wijaya1, Muhammad Husnul Maab1, Chamid Sutikno1, dan Diar Budi Utama²}

\author{
${ }^{1}$ Dosen Program Studi Administrasi Publik, Universitas Nahdlatul Ulama, Purwokerto, Indonesia \\ 2Mahasiswa Program Studi Manajemen Bencana, Universitas Pertahanan, Indonesia \\ *Email: zr.atika@unupurwokerto.ac.id
}

\begin{abstract}
Abstrak
Pemerintah Daerah Kabupaten Purbalingga pada tahun 2016 memiliki 32 unit kerja beragam. Upaya untuk melihat kualitas penyelenggaraan pelayanan publik salah satunya melalui Survei Kepuasan Masyarakat (SKM). Adapun metode penelitian yang dipilih adalah survei dengan menggunakan kuesioner sebagai instrumen utama. Lokasi penelitian berada pada tujuh instansi yakni DPMPTSP, Dinas Arsip dan Perpustakaan, Dinas Tenaga Kerja, Kecamatan Mrebet, RSUD dr. Goeteng Taroenadibrata, UPTD Puskesmas Mrebet, dan UPTD Puskeswan. Populasi penelitian adalah mereka yang pernah mendapatkan pelayanan pada lokasi penelitian. Penentuan untuk jumlah sampel dilakukan menggunakan Tabel Morgan dan Krejcie dan diperoleh total sampel sebesar 2.279 responden. Penelitian dilakukan dalam kurun waktu dua minggu. Mengacu Kepmen PAN No. 14 Tahun 2017 tentang Pedoman Penyusunan Survei Kepuasan Masyarakat Unit Penyelenggara Pelayanan Publik, nilai IKM dihitung dengan menggunakan nilai ratarata tertimbang unsur pelayanan yang disurvei. Dalam penelitian ini ada 9 unsur pelayanan yang dinilai meliputi beberapa unsur diantaranya persyaratan, sistem, mekanisme dan prosedur, waktu penyelesaian, biaya/tarif, produk spesifikasi jenis pelayanan, kompetensi pelaksana, perilaku pelaksana, penangan pengaduan, saran dan masukan, serta sarana dan prasarana. Ketujuh OPD yang disurvei ada enam OPD yang mendapatkan nilai SKM pada kategori baik dan ada satu OPD yang mendapatkan nilai SKM pada kategori kurang baik. Nilai SKM yang tinggi menunjukkan bahwa pelayanan yang diberikan oleh OPD sudah melebihi harapan dari pengguna layanan. Nilai SKM tertinggi sebesar 80.62 dengan kategori kinerja layanan Baik (B) diperoleh Dinas Arsip dan Perpustakaan. Sedangkan nilai SKM terendah sebesar 75.64 dengan kategori layanan Kurang Baik (C) diperoleh Dinas Penanaman Modal dan Pelayanan Terpadu Satu Pintu (DPMPTSP). Secara umum, hasil penelitian menunjukkan bahwa SKM pada OPD di Kabupaten Purbalingga masuk kategori Baik (B) yakni pada rentang 76.61 - 88.30. Hal ini berarti secara umum instansi tersebut telah mampu memberikan pelayanan dengan baik sesuai dengan harapan masyarakat. Perilaku pelaksana berpengaruh terhadap semua unsur.
\end{abstract}

Kata Kunci: Kepuasan Masyarakat, Kualitas Pelayanan, Pelayanan Publik, Pemerintah Daerah, Kabupaten Purbalingga

\section{PENDAHULUAN}

Perkembangan pelayanan publik di Indonesia beberapa tahun terakhir berada dalam kondisi dimana tuntutan masyarakat cukup tinggi untuk mendapatkan pelayanan publik secara berkualitas. Seiring perkembangan zaman, kesadaran masyarakat semakin bertambah atas hak dan kewajiban sebagai warga negara dalam hidup bermasyarakat, berbangsa dan bernegara. Masyarakat saat ini cukup berani untuk mengajukan tuntutan, keinginan dan aspirasinya kepada pemerintah. Masyarakat juga semakin kritis melakukan kontrol terhadap pemerintah. Secara umum pelayanan publik berperan penting dalam penyelenggaraan 
pemerintahan. Program Pembangunan Nasional (Propenas) mengamanatkan perlunya melakukan kegiatan pelayanan publik yang berkualitas baik dari perspektif akuntabilitas, transparansi dan supremasi hukum sebagai wujud Good Government. Hal tersebut dikarenakan pelayanan publik berkaitan dengan aspek kehidupan yang sangat luas.

Keberadaan pelayanan publik sekaligus jawaban atas kebutuhan dasar masyarakat ataupun hak atas setiap warga negarany untuk mendapatkan barang, jasa, serta pelayanan administrasi yang disediakan penyelenggara pelayanan publik. Berbicara mengenai pelayanan publik, seringkali akan dikaitkan dengan tingkat kepuasan masyarakat. Salah satu keberhasilan dari penyelenggaraan pelayanan publik adalah besarnya tingkat kepuasan masyarakat atas pelayanan yang diberikan. Kepuasan masyarakat dapat tercapai melalui pemberian pelayanan yang berkualitas. Pelayanan publik diberikan kepada masyarakat pada hakikatnya merupakan implikasi dari fungsi aparat negara sebagai pelayan masyarakat. Kedudukan pemerintah dalam pelayanan publik sangat strategis, dimana nantinya akan menentukan sejauh mana pemerintah mampu memberikan pelayanan yang baik bagi masyarakat serta sejauh mana Negara telah menjalankan perannya sesuai tujuan pendiriannya. Faktanya, beberapa tahun terakhir penyelenggaraan pelayanan publik di Indonesia justru kerap kali disorot dari keluhan masyarakat.

Pada awal tahun 2017, terdapat beberapa instansi di Indonesia yang cukup banyak mendapatkan laporan masyarakat berkaitan dengan penyelenggaraan pelayanan publik. Pemerintah Daerah merupakan instansi yang paling banyak mendapatkan laporan masyarakat sebesar 40\%, kemudian Kepolisian menyusul dengan persentase laporan masyarakat sebanyak 12,8\%. Instansi terlapor berikutnya berasal dari Lembaga Pendidikan Negeri sebesar 8,0\%, lalu Rumah Sakit Pemerintah terlapor dengan persentase sebanyak 0,8\% dan terakhir yaitu Tentara Nasional Indonesia (TNI) mendapatkan laporan dari masyarakat hanya 0,3\% (Laporan Masyarakat oleh Ombudsman RI Tahun 2017). Data tersebut menunjukkan bahwa Pemerintah Daerah paling banyak disorot berkaitan dengan kualitas pelayanan publik. Sebagaimana dijelaskan dalam data Laporan Masyarakat oleh Ombudsman RI Tahun 2017 bahwa sebagian besar masyarakat mengeluhkan adanya dugaan maladministrasi pada penundaan berlarut sebesar 28,7\% atau berasal dari 569 laporan. Dugaan maladministrasi pelayanan publik selanjutnya adalah mengenai penyimpangan prosedur sebanyak 458 laporan atau $23,1 \%$ dari masyarakat.

Pemerintah Provinsi Jawa Tengah pada awal tahun 2017 menempati peringkat sembilan dari beberapa wilayah di Indonesia yang cukup banyak mendapatkan keluhan masyarakat mengenai penyelenggaraan pelayanan publik. Terdapat 64 keluhan masyarakat terkait penyelenggaraan pelayanan publik yang telah dilaporkan ke Kantor Perwakilan Ombudsman Provinsi Jawa Tengah. Angka tersebut jauh lebih besar dibandingkan Pemerintah Provinsi Jawa 
Barat yang hanya mendapatkan 36 laporan masyarakat berkaitan penyelenggaraan pelayanan publik. Hal ini membuktikan bahwa masyarakat seiring berjalannya waktu ikut berperan dalam proses penyelenggaraan pelayanan publik. Kondisi serupa hampir dialami pula oleh sebagian besar pemerintah daerah di Indonesia. Terlebih lagi pemerintah daerah menjadi instansi yang paling banyak mendapatkan laporan masyarakat sebesar $40 \%$.

Kabupaten Purbalingga merupakan salah satu wilayah di Provinsi Jawa Tengah yang tidak terlepas dari sorotan masyarakat atas proses penyelenggaraan pelayanan publik. Pemerintah Daerah Kabupaten Purbalingga tahun 2016 memiliki 32 unit kerja. Pegawai Negeri Sipil (PNS) pada Pemerintah Daerah Kabupaten Purbalingga tahun 2016 tercatat sebanyak 8.062 orang terdiri dari 4.115 orang laki-laki dan 3.947 orang perempuan. Adapun rincian menurut penggolongan pegawai meliputi golongan I sebanyak 148 orang, golongan II berjumlah 1.456 orang, golongan III sebanyak 3.684 orang dan golongan IV berjumlah 2.774 orang (Kabupaten Purbalingga Dalam Angka Tahun 2017).

Unit pelayanan publik sangat beragam baik di Indonesia umumnya, maupun di Kabupaten Purbalingga khususnya. Upaya untuk melihat kualitas penyelenggaraan pelayanan publik salah satunya melalui Survei Kepuasan Masyarakat (SKM), tentunya dengan metode survei yang seragam. Survei Kepuasan Masyarakat (SKM) merupakan kegiatan pengukuran yang dilakukan secara komperehensif berupa tingkat kepuasan masyarakat terhadap kualitas layanan yang diberikan oleh penyelenggara pelayanan publik. Peraturan Menteri Pendayagunaan Aparatur Negara dan Reformasi Birokrasi Republik Indonesia Nomor 14 Tahun 2017 tentang Pedoman Penyusunan Survei Kepuasan Masyarakat (SKM) Unit Penyelenggara Pelayanan Publik mengamanatkan bahwa kegiatan Survei Kepuasan Masyarakat (SKM) harus disesuaikan menggunakan metode survei yang aplikatif dan mudah dilaksanakan. Peraturan ini sekaligus memberikan arahan serta pedoman yang cukup jelas dan tegas bagi penyelenggara pelayanan publik.

Tujuan dari penyelenggaraan kegiatan ini yaitu untuk mengukur tingkat kepuasan masyarakat Kabupaten Purbalingga dari sisi pengguna layanan dan meningkatkan kualitas penyelenggaraan pelayanan publik dengan menggunakan indikator dan metodologi survei yang sudah ditentukan. Berdasarkan hal tersebut, maka kegiatan Penyusunan Survei Kepuasan Masyarakat (SKM) Pemerintah Kabupaten Purbalingga Tahun 2017 sangat penting untuk dilakukan.

\section{TINJAUAN PUSTAKA}

Pelayanan dapat dikatakan memuaskan jika pelayanan tersebut telah memenuhi kebutuhan serta harapan masyarakat. Apabila masyarakat tidak puas terhadap suatu pelayanan yang disediakan, maka pelayanan tersebut dapat dipastikan tidak berkualitas atau 
tidak efisiensi (Hardiyansnyah, 2011:36). Kualitas pelayanan sangat ditentukan oleh kepuasan pelanggan. Kepuasan pelanggan sangat subjektif tergantung bagaimana mereka menilai pelayanan yang diterima. Waykof (dalam Purnama, 2006:19), menyatakan bahwa kualitas layanan sebagai tingkat kesempurnaan yang diharapkan dan pengendalian atas kesempurnaan tersebut untuk memenuhi keinginan konsumen. Sedangkan Parasuraman et al. (dalam Purnama, 2006:19), mendefinisikan bahwa kualitas layanan menjadi perbandingan antara layanan yang dirasakan (persepsi) konsumen dengan kualitas layanan yang diharapkan konsumen. Apabila kualitas layanan yang dirasakan sama atau melebihi kualitas layanan yang diharapkan, maka layanan tersebut dikatakan berkualitas dan memuaskan kepada konsumen atau pelanggannya.

Mengacu Kepmen PAN No.14 Tahun 2017 tentang Pedoman Penyusunan Survei Kepuasan Masyarakat Unit Penyelenggara Pelayanan Publik, nilai IKM dihitung dengan menggunakan nilai rata-rata tertimbang unsur pelayanan yang disurvei. Dalam penelitian ini ada 9 unsur pelayanan yang dinilai yaitu meliputi unsur persyaratan, sistem, mekanisme dan prosedur, waktu penyelesaian, biaya/tarif, produk spesifikasi jenis pelayanan, kompetensi pelaksana, perilaku pelaksana, penangan pengaduan, saran dan masukan, serta sarana prasarana.

\section{METODE PENELITIAN}

Metode dalam penyusunan Survei Kepuasan Masyarakat (SKM) di Kabupaten Purbalingga yakni menggunakan survei periodik, dimana survei dilakukan untuk penyelenggara pelayanan publik terkait layanan publik yang diberikan kepada masyarakat. Survei periodik dilaksanakan secara tetap dengan jangka waktu tertentu. Pendekatan yang digunakan oleh survei periodik yaitu metode kualitatif berupa wawancara dan kuantitatif melalui pengukuran skala likert. Survei periodik bersifat komprehensif, hasil analisa survei nantinya dipergunakan untuk mengevaluasi kepuasan masyarakat terhadap layanan yang diberikan. Selain itu, hasil survei digunakan sebagai bahan kebijakan terhadap pelayanan publik serta melihat kecenderungan (trend) dalam penyelenggaraan pelayanan publik. Sampel yang digunakan dalam Survei Kepuasan Masyarakat di Kabupaten Purbalingga diperoleh dari hasil penghitungan total populasi di tiap instansi dalam satu tahun menggunakan tabel Morgan \& Krejcie dengan hasil sebagai berikut:

Tabel 1. Penghitungan Total Populasi Dan Sampel SKM

\begin{tabular}{llccc}
\hline No & \multicolumn{1}{c}{ Instansi } & Populasi & $\begin{array}{c}\text { Sampel } \\
\text { (berdasarkan Tabel } \\
\text { Morgan \& Krejcie) }\end{array}$ & $\begin{array}{c}\text { Kuesioner yang } \\
\text { kembali \& dapat } \\
\text { diproses }\end{array}$ \\
\hline \multirow{2}{*}{1} & $\begin{array}{l}\text { Dinas Penanaman Modal \& } \\
\text { Pelayanan Terpadu Satu Pintu } \\
\text { (DPMPTSP) }\end{array}$ & 1.551 & 310 & $100 \%$ \\
\hline 2 & Dinas Arsip \& Perpustakaan & 44.346 & 380 & $100 \%$ \\
\hline 3 & Dinas Tenaga Kerja & 234.474 & 384 & $100 \%$ \\
\hline
\end{tabular}




\begin{tabular}{llrrr}
\hline 4 & Kecamatan Mrebet & 6.557 & 364 & $100 \%$ \\
\hline 5 & RSUD dr.Goeteng T. & 161.962 & 384 & $100 \%$ \\
\hline 6 & UPTD Puskesmas Mrebet & 17.679 & 377 & $100 \%$ \\
\hline 7 & UPTD Puskeswan & 99 & 80 & $100 \%$ \\
\hline Total & & $\mathbf{4 6 6 . 6 6 8}$ & $\mathbf{2 2 7 9}$ & $\mathbf{1 0 0 \%}$ \\
\hline
\end{tabular}

Berdasarkan tabel di atas diketahui bahwa jumlah populasi dari ke tujuh instansi sebesar 466.668 orang. Penentuan jumlah sampel didasarkan besarnya populasi masing-masing instansi, sehingga diperoleh total sampel sebesar 2.279 orang. Adapun rincian besarnya sampel di tiap instansi dapat dilihat pada tabel di atas. Jumlah kuesioner yang tersebar adalah sejumlah sampel di tiap instansi. Dari seluruh kuesioner yang disebar, semua terisi lengkap dan dapat diolah untuk keperluan analisis data.

\section{HASIL DAN PEMBAHASAN}

Sebagaimana yang disampaikan dalam Kepmen PAN No. 14 Tahun 2017 tentang Pedoman Penyusunan Survei Kepuasan Masyarakat Unit Penyelenggara Pelayanan Publik, nilai IKM dihitung dengan menggunakan nilai rata-rata tertimbang unsur pelayanan yang disurvei. Dalam penelitian ini ada 9 unsur pelayanan yang dinilai yaitu meliputi unsur persyaratan, sistem, mekanisme dan prosedur, waktu penyelesaian, biaya/tarif, produk spesifikasi jenis pelayanan, kompetensi pelaksana, perilaku pelaksana, penangan pengaduan, saran dan masukan, serta sarana prasarana. Adapun 7 (tujuh) OPD yang dinilai kualitas pelayanan masyarakatnya meliputi DPMPTSP, Dinas Arsip dan Perpustakaan, Dinas Tenaga Kerja, Kecamatan Mrebet, RSUD dr. Goeteng Taroenadibrata, UPTD Puskesmas Mrebet dan UPTD Puskeswan.

\section{DINAS PENANAMAN MODAL DAN PELAYAN TERPADU SATU PINTU (DPMPTSP)}

Kajian survei kepuasan masyarakat yang dilakukan di DPMPTSP Kab. Purbalingga ini dilakukan terhadap 310 responden. Responden adalah masyarakat yang sedang dan pernah memanfaatkan jasa pelayanan di DPMPTSP tersebut yang dipilih secara acak. Berdasarkan jenis kelamin responden, diketahui bahwa secara mayoritas responden dalam survei ini adalah laki-laki sebanyak 209 responden atau 67,4 persen dari keseluruhan responden. Sedangkan responden perempuan sebanyak 101 orang atau 32,6 persen. Hal ini menunjukkan bahwa jumlah masyarakat laki-laki yang mendapatkan pelayanan di DPMPTSP lebih banyak dibandingkan masyarakat perempuan. Mayoritas pelayanan yang diselenggarakan oleh DPMPTSP diakses oleh kelompok masyarakat produktif dengan tingkat pendidikan terakhir SMA. Sebagian besar penerima layanan dari DPMPTSP adalah mereka para wirausahawan dan pekerja swasta yang mengakses layanan DPMPTSP untuk mendapatkan izin usaha perdagangan dan IMB. 
Mayoritas jawaban responden pada masing-masing unsur pelayanan masuk kategori baik, namun unsur biaya dan penanganan pengaduan mayoritas jawaban responden masuk kategori sangat baik. Dari seluruh responden, tidak ada yang memberikan jawaban pada kategori tidak baik, kecuali pada unsur penanganan pengaduan, saran dan masukan. Berdasarkan hasil korelasi diketahui bahwa setiap unsur pelayanan berkorelasi dengan unsur pelayanan yang lainnya dan hampir secara keseluruhan berkorelasi secara signifikan. Misal Unsur perilaku pelaksana memiliki korelasi yang tinggi dengan unsur lainnya, secara positif dan signifikan. Hal ini berarti semakin baik perilaku pelaksananya maka akan semakin sesuai persyaratannya, semakin cepat waktu pelayanannya, semakin berkompeten pelaksananya, semakin baik penanganan pengaduan, saran dan masukkan serta semakin baik sarana dan prasarananya. Begitupula sebaliknya semakin tidak mudah prosedurnya maka akan semakin tidak sesuai persyaratannya, penanganan pengaduan, saran dan masukkan tidak dikelola dengan baik, serta sarana dan prasarana yang semakin buruk, sehingga dapat dikatakan bahwa kinerja DPMPTSP Kabupaten Purbalingga tahun 2017 berdasarkan tabel SKM memperoleh nilai Kurang Baik (C) dengan angka 75,64. Nilai tersebut tergolong nilai yang medekati baik. Dari seluruh unsur pelayanan yang ada, nilai tertinggi terpadat pada unsur biaya $(95,73)$, sedangkan nilai terendah terdapat pada unsur Sarana \& Prasarana $(66,21)$.

\section{DINAS ARSIP DAN PERPUSTAKAAN}

Kajian survei kepuasan masyarakat yang dilakukan di Dinas Arsip dan Perpustakaan Daerah Kab. Purbalingga ini dilakukan terhadap 380 responden. Responden adalah masyarakat yang sedang dan pernah memanfaatkan jasa pelayanan di Dinas Arsip dan Perpustakaan Daerah tersebut yang dipilih secara acak. Berdasarkan jenis kelamin responden, diketahui bahwa secara mayoritas responden dalam survei ini adalah laki-laki sebanyak 127 responden atau 33,4 persen dari keseluruhan responden. Sedangkan responden perempuan sebanyak 253 orang atau 66,6 persen. Hal ini menunjukkan bahwa jumlah masyarakat perempuan yang mengakses pelayanan di Dinas Arsip dan Perpustakaan Daerah lebih banyak dibandingkan masyarakat laki-laki. Sebagian besar penerima layanan dari Dinas Arsip dan Perpustakaan Daerah adalah mereka para pelajar. Mayoritas responden datang ke Perpusda bertujuan untuk membaca, yakni sebanyak 198 orang (52,1 persen) dan meminjam bahan pustaka, sejumlah 132 orang (34,7 persen). Selebihnya sejumlah 50 orang (13,2 persen) adalah mengakses layanan lainnya, seperti membuat kartu anggota perpusda, studi banding dan kunjungan dinas.

Mayoritas jawaban responden pada masing-masing unsur pelayanan masuk kategori baik, namun unsur biaya dan penanganan pengaduan mayoritas jawaban responden masuk kategori sangat baik. Seluruh responden tidak ada yang memberikan jawaban pada kategori tidak baik. Berdasarkan hasil korelasi diketahui bahwa setiap unsur pelayanan berkorelasi 
dengan unsur pelayanan yang lainnya. Korelasi tertinggi dengan nilai 0,514 berada pada tingkat hubungan sedang yakni antara unsur persyaratan dan unsur prosedur. Hal ini menunjukkan bahwa semakin baik atau lengkap persyaratan yang dimiliki oleh pengguna layanan akan semakin baik atau mudah prosedur pelayanannya. Begitu juga sebaliknya,semakin tidak sesuai persyaratan yang dimiliki pengguna layanan maka akan semakin sulit prosedur pelayanannya. Temuan yang menarik dari hasil survei ini adalah adanya korelasi secara positif dan signifikan antara unsur sarana prasarana terhadap semua unsur, kecuali unsur biaya. Hubungan antara sarana prasarana dan biaya adalah negatif dan signifikan. Hal ini menegaskan bahwa untuk memperoleh sarana dan prasarana yang lebih baik maka harus didukung dengan biaya yang lebih tinggi.

Berdasarkan tabel SKM dapat diketahui bahwa nilai Kinerja Dinas Tenaga Kerja \& Transmigrasi Kabupaten Purbalingga tahun 2017 memperoleh nilai Baik (B) dengan angka 79,03. Dari seluruh unsur pelayanan yang ada, nilai tertinggi terpadat pada unsur biaya $(91,75)$, sedangkan nilai terendah terdapat pada unsur Sarana \& Prasarana $(75,19)$.

\section{DINAS TENAGA KERJA}

Kajian survei kepuasan masyarakat yang dilakukan di Dinas Tenaga Kerja Kab. Purbalingga ini dilakukan terhadap 384 responden. Responden adalah masyarakat yang sedang dan pernah memanfaatkan jasa pelayanan di Dinas Tenaga Kerja tersebut yang dipilih secara acak. Berdasarkan jenis kelamin responden, diketahui bahwa secara mayoritas responden dalam survei ini adalah laki-laki sebanyak 206 responden atau 53,6 persen dari keseluruhan responden. Sedangkan responden perempuan sebanyak 178 orang atau 46,4 persen. Hal ini menunjukkan bahwa jumlah masyarakat laki-laki yang mendapatkan pelayanan di Dinas Tenaga Kerja lebih banyak dibandingkan masyarakat perempuan.

Berdasarkan rentang umur tersebut dapat disimpulkan bahwa pengguna layanan di Dinas Tenaga Kerja sebagian besar adalah mereka calon tenaga kerja atau tenaga kerja muda. Tingkat pendidikan sebagian besar responden adalah SMA. Hal ini menunjukkan bahwa sebagian besar responden telah menamatkan program wajib belajar 12 tahun. Secara mayoritas, responden adalah para pencari kerja yakni sebanyak 212 responden atau 55,2 persen dari keseluruhan responden. Kemudian mereka yang bekerja dibidang swasta sebanyak 127 responden atau 33,1 persen dari keseluruhan responden. Kemudian buruh sebanyak 22 responden (5,7 persen), PNS/TNI/Polri sebanyak 12 responden (3,1 persen), wirausaha sebanyak 8 responden (2,1 persen), dan pelajar sebanyak 3 responden (0,8 persen). Hal ini menunjukkan bahwa sebagian besar penerima layanan dari Dinas Tenaga Kerja adalah mereka para pencari kerja. Mayoritas penerima layanan adalah pembuatan kartu kuning. Hal tersebut dibuktikan oleh sebanyak 245 responden (63,8 persen) dari keseluruhan responden merupakan pembuat kartu kuning. Sedangkan sebanyak 76 responden (19,8 persen) adalah 
penerima pelayanan lainnya. Pelayanan lainnya ini berupa melihat lowongan kerja yang berada di Dinas Tenaga Kerja.

Mayoritas jawaban responden pada masing-masing unsur pelayanan masuk kategori baik, namun unsur biaya dan penanganan pengaduan mayoritas jawaban responden masuk kategori sangat baik. Dari seluruh responden, tidak ada yang memberikan jawaban pada kategori tidak baik, kecuali pada unsur penanganan pengaduan, saran dan masukan. Korelasi tertinggi dengan nilai 0,514 berada pada tingkat hubungan sedang yakni antara unsur persyaratan dan unsur prosedur. Hal ini menunjukkan bahwa semakin baik atau lengkap persyaratan yang dimiliki oleh pengguna layanan akan semakin baik atau mudah prosedur pelayanannya. Begitu juga sebaliknya,semakin tidak sesuai persyaratan yang dimiliki pengguna layanan maka akan semakin sulit prosedur pelayanannya. Temuan yang menarik dari hasil survei ini adalah adanya korelasi secara positif dan signifikan antara unsur sarana prasarana terhadap semua unsur, kecuali unsur biaya. Hubungan antara sarana prasarana dan biaya adalah negatif dan signifikan. Berdasarkan tabel SKM dapat diketahui bahwa nilai Kinerja Dinas Tenaga Kerja \& Transmigrasi Kabupaten Purbalingga tahun 2017 memperoleh nilai Baik (B) dengan angka 79,03. Dari seluruh unsur pelayanan yang ada, nilai tertinggi terpadat pada unsur biaya $(91,75)$, sedangkan nilai terendah terdapat pada unsur Sarana \& Prasarana $(75,19)$.

\section{KECAMATAN MREBET}

Kajian survei kepuasan masyarakat yang dilakukan di Kecamatan Mrebet Kab. Purbalingga ini dilakukan terhadap 364 responden. Responden adalah masyarakat yang sedang dan pernah memanfaatkan jasa pelayanan di Kecamatan Mrebet tersebut yang dipilih secara acak. Berdasarkan jenis kelamin responden, diketahui bahwa secara mayoritas responden dalam survei ini adalah perempuan sebanyak 211 responden (58 persen) dari keseluruhan responden. Sedangkan responden laki-laki sebanyak sebanyak 153 responden (42 persen). Hal ini menunjukkan bahwa jumlah perempuan yang mendapatkan pelayanan di Kecamatan Mrebet lebih banyak dibandingkan laki-laki.

Berdasarkan rentang umur, dapat disimpulkan bahwa pengguna layanan di Kecamatan Mrebet sebagian besar adalah berusia dewasa. Pada hasil penelitian diketahui bahwa tingkat pendidikan sebagian besar responden adalah SLTP. Hal tersebut dibuktikan oleh 150 responden atau 41,2 persen dari keseluruhan responden memiliki tingkat pendidikan SMP. Kemudian disusul oleh mereka yang memiliki pendidikan SMA sebesar 108 responden atau 29.2 persen, pendidikan S1 dan SD masing-masing sebesar 74 responden atau 21.4 persen. Hal ini menunjukkan bahwa sebagian besar responden telah menamatkan program wajib belajar 12 tahun. 
Secara mayoritas, responden adalah para ibu rumah tangga yakni sebanyak 139 responden (38.2 persen) dari keseluruhan responden. Kemudian mereka yang bekerja dibidang wirausaha sebanyak 70 responden (19.2 persen) dari keseluruhan responden. Kemudian swasta sebanyak 67 responden (18.4 persen), buruh sebanyak 35 responden (9.6 persen), PNS/TNI/Polri sebanyak 26 responden (7,1 persen), petani sebanyak 13 responden (3.6 persen), dan belum bekerja sebanyak 14 responden (3,8 persen). Hal ini menunjukkan bahwa sebagian besar penerima layanan dari Kecamatan Mrebet adalah mereka para Ibu rumah tangga.

Sebanyak 96 responden (26.4 persen) dari keseluruhan responden merupakan penerima pelayanan surat pengantar KK. Sedangkan sebanyak 88 responden (24.2 persen) adalah penerima pelayanan surat keterangan KTP, sebanyak 79 responden (21.7 persen) penerima layanan legalisasi, sebanyak 43 responden (11.8 persen) penerima layanan surat keterangan pindah tempat, sebanyak 36 responden mendapatkan pelayanan lainnya, sebanyak 21 responden mendapatkan surat pengantar SKCK dan sebanyak 1 responden mendapatkan pelayanan rekomendasi IMB. Pelayanan lainnya antara lain surat pernyataan belum pernah menikah, surat rekomendasi beasiswa dari desa dan surat pengantar akte kelahiran maupun surat keterangan kematian. Dapat disimpulkan bahwa sebagian besar responden adalah penerima layanan surat pengantar KK.

Mayoritas jawaban responden pada masing-masing unsur pelayanan masuk kategori baik, namun unsur biaya mayoritas jawaban responden masuk kategori sangat baik. Dari seluruh responden, tidak ada yang memberikan jawaban pada kategori tidak baik, kecuali pada unsur waktu penyelesaian dan penanganan pengaduan, saran dan masukan. Berdasarkan tabel SKM di atas, dapat diketahui bahwa nilai Puskesmas Mrebet Tahun 2017 memperoleh nilai Baik (B) dengan angka 80.69. Dari seluruh unsur pelayanan yang ada, nilai tertinggi terpadat pada unsur biaya $(96,28)$, sedangkan nilai terendah terdapat pada unsur penanganan pengaduan, saran dan masukan $(73,90)$.

\section{RSUD dr.GOETENG TARONADIBRATA}

Kajian survei kepuasan masyarakat yang dilakukan di RSUD dr. Goeteng Taronadibrata ini dilakukan terhadap 384 responden. Responden adalah masyarakat yang sedang dan pernah memanfaatkan jasa pelayanan di RSUD dr. Goeteng Taronadibrata tersebut yang dipilih secara acak. Berdasarkan jenis kelamin responden, diketahui bahwa secara mayoritas responden dalam penelitian ini adalah laki-laki sebanyak 165 responden atau 43 persen dari keseluruhan responden. Sedangkan responden perempuan sebanyak 219 orang atau 57 persen. Hal ini menunjukkan bahwa jumlah masyarakat laki-laki yang mendapatkan pelayanan di RSUD dr. Goeteng Taronadibrata lebih banyak perempuan. Sebagian besar responden berumur sekitar 36 - 45 tahun. Hal tersebut dibuktikan oleh sejumlah 143 responden atau 37.2 persen dari 
keseluruhan responden berumur pada rentang tersebut. Selanjunya adalah responden paling sedikit berusia 66 tahun ke atas sebanyak 16 responden atau 4.2 persen.

Tingkat pendidikan sebagian besar responden adalah SD. Hal tersebut dibuktikan oleh 144 responden atau 37.5 persen dari keseluruhan responden memiliki tingkat pendidikan SD. Kemudian disusul oleh mereka yang memiliki pendidikan SMP sebesar 111 responden atau 28,9 persen, pendidikan SMA sebesar 95 responden atau 24.7 persen. Memiliki pendidikan S1 sebesar 34 orang atau 8.9 persen. Hal ini menunjukkan bahwa sebagian besar responden memiliki pendidikan yang rendah. Secara mayoritas, responden memiliki pekerjaan dibidang swasta sebanyak 107 responden atau 27.9 persen dari keseluruhan responden. Kemudian IRT/Pensiunan/Tidak bekerja sebanyak 101 responden (26.3 persen). Responden dalam terendah adalah pelajar/mahasiswa sebanyak 9 responden persen). Hal ini menunjukkan bahwa sebagian besar penerima layanan dari RSUD dr. Goeteng Taronadibrata adalah pegawai swasta dan IRT/Pensiunan/Tidak bekerja.

Responden terbesar adalah klinik dalam dengan jumlah 84 atau 21,9\%, kedua klinik syaraf dengan jumlah 78 atau 20,3, ketiga klinik anak dengan jumlah 46 atau 12,0\%. Sedangkan untuk jumlah sampel terkecil adalah klinik bedah anak dengan jumlah 2 atau 6,3\%, kedua klinik orthopaedi dengan jumlah 12 atau 3,1, ketiga klinik gigi dan klinik THT dengan jumlah yang sama yaitu 14 atau 3,6\%. Jumlah responden pada unit layanan RSUD dr. Goeteng Taronadibrata adalah sebesar 384 orang. Mayoritas jawaban responden pada masing-masing unsur pelayanan masuk kategori baik, namun unsur biaya dan penanganan pengaduan mayoritas jawaban responden masuk kategori sangat baik. Dari seluruh responden, tidak ada yang memberikan jawaban pada kategori tidak baik, kecuali pada unsur waktu pelayanan, unsur penanganan pengaduan, saran dan masukan dan unsur sarana prasarana.

Korelasi tertinggi dengan nilai 0,444 berada pada tingkat hubungan sedang yakni antara unsur persyaratan dan unsur prosedur. Hal ini menunjukkan bahwa semakin baik atau lengkap persyaratan yang dimiliki oleh pengguna layanan akan semakin baik atau mudah prosedur pelayanannya. Begitu juga sebaliknya,semakin tidak sesuai persyaratan yang dimiliki pengguna layanan maka akan semakin sulit prosedur pelayanannya. Berdasarkan tabel SKM, dapat diketahui bahwa nilai Kinerja RSUD dr. Goeteng Taronadibrata tahun 2017 memperoleh nilai Baik (B) dengan angka 78,29. Dari seluruh unsur pelayanan yang ada, nilai tertinggi pada unsur biaya $(92,70)$, sedangkan nilai terendah terdapat pada unsur penangan pengaduan, saran dan masukan (71.45).

\section{UPTD PUSKESMAS MREBET}

Kajian survei kepuasan masyarakat yang dilakukan di Puskesmas Mrebet ini dilakukan terhadap 377 responden. Responden adalah masyarakat yang sedang dan pernah memanfaatkan jasa pelayanan di Puskesmas Mrebet tersebut yang dipilih secara acak. 
Berdasarkan jenis kelamin responden, diketahui bahwa secara mayoritas responden dalam survei ini adalah perempuan sebanyak 244 responden (64.7 persen) dari keseluruhan responden. Sedangkan responden laki-laki sebanyak sebanyak 133 responden (35.3 persen). Hal ini menunjukkan bahwa jumlah perempuan yang mendapatkan pelayanan di Kecamatan Mrebet lebih banyak dibandingkan laki-laki. Berdasarkan rentang umur tersebut dapat disimpulkan bahwa pengguna layanan di Kecamatan Mrebet sebagian besar adalah berusia dewasa. Tingkat pendidikan sebagian besar responden adalah SD. Hal tersebut dibuktikan oleh 162 responden atau 43 persen dari keseluruhan responden memiliki tingkat pendidikan SD. Kemudian disusul oleh mereka yang memiliki pendidikan SMP sebesar 107 responden atau 28,4 persen, pendidikan SMA sebesar 66 responden atau 17,5 persen. Memiliki pendidikan S1 sebesar 42 orang atau 11.1 persen. Hal ini menunjukkan bahwa sebagian besar responden memiliki pendidikan formal yang rendah.

Secara mayoritas, responden adalah ibu rumah tangga yakni sebanyak 159 responden atau 42,2 persen dari keseluruhan responden. Kemudian mereka yang bekerja dibidang swasta sebanyak 64 responden atau 17 persen dari keseluruhan responden. Kemudian petani/buruh/sopir sebanyak 46 responden (12.2 persen), wirausaha sebanyak 44 responden (17 persen), PNS/TNI/Polri/Guru sebanyak 23 responden (6,1 persen), dan pelajar/belum bekerja sebanyak 23 responden (5.3 persen) dan pensiunan sebanyak 12 responden (3.2 persen). Hal ini menunjukkan bahwa sebagian besar penerima layanan dari Puskesmas Mrebet adalah mereka Ibu rumah tangga. Sebanyak 156 responden (41.4 persen) dari keseluruhan responden mendapatkan pelayanan dari poli umum. Selanjutnya adalah pada poli KIA/KB sebanyak 103 responden (27.3 persen). Selanjutnya sebanyak 77 responden (20.4 persen) adalah penerima layanan pada poli gigi. Kemudian sebanyak 33 responden (8.8 persen) mendapatkan pelayanan lainnya. Pelayanan lainnya ini berupa pelayanan pengecekan kesehatan dan rawat inap. Masing-masing pelayanan konseling kesehatan dan laboratorium ada 4 responden (1.1 persen). Secara umum, dilihat dari layanan yang diterima, mayoritas responden mendapatkan pelayanan poli umum.

Mayoritas jawaban responden pada masing-masing unsur pelayanan masuk kategori baik, namun unsur biaya dan penanganan pengaduan mayoritas jawaban responden masuk kategori sangat baik. Dari seluruh responden, tidak ada yang memberikan jawaban pada kategori tidak baik, kecuali pada unsur penanganan pengaduan, saran dan masukan. Korelasi tertinggi dengan nilai 0,404 berada pada tingkat hubungan sedang yakni antara unsur persyaratan dan unsur kompetensi pelaksana. Hal ini menunjukkan bahwa semakin baik atau lengkap persyaratan yang dimiliki oleh pengguna layanan akan semakin baik atau berkompeten pelaksananya. Begitu juga sebaliknya,semakin tidak sesuai persyaratan yang dimiliki pengguna layanan maka akan semakin sulit kompetensi yang dimiliki pelaksana. 
Temuan yang menarik dari hasil survei ini adalah adanya korelasi secara positif dan signifikan antara unsur persyaratan, unsur prosedur, unsur kompetensi, unsur pengelolalan pengaduan, dan unsur sarana prasarana terhadap semua unsur. Hal ini menegaskan bahwa semakin baik unsur persyaratan, unsur prosedur, unsur kompetensi, unsur pengelolalan pengaduan, dan unsur sarana prasarana maka kualitas layanan akan semakin baik.

Berdasarkan tabel SKM, dapat diketahui bahwa nilai Kinerja Puskesmas Mrebet tahun 2017 memperoleh nilai Baik (B) dengan angka 76,70. Dari seluruh unsur pelayanan yang ada, nilai tertinggi terdapat pada unsur biaya $(96,09)$, sedangkan nilai terendah terdapat pada unsur Sarana \& Prasarana $(73,14)$.

\section{UPTD PUSAT KESEHATAN HEWAN (PUSKESWAN)}

Kajian indeks kepuasan masyarakat yang dilakukan di Puskeswan Kab. Purbalingga ini dilakukan terhadap 80 responden. Responden adalah masyarakat yang sedang dan pernah memanfaatkan jasa pelayanan di Puskeswan tersebut yang dipilih secara acak. Berdasarkan rentang umur tersebut dapat disimpulkan bahwa pengguna layanan di UPTD Puskeswan sebagian besar adalah peternak pemula yang berada pada rentang usia produktif.

Tingkat pendidikan sebagian besar responden adalah SMA. Hal tersebut dibuktikan oleh 53 responden atau 66,3 persen dari keseluruhan responden memiliki tingkat pendidikan SMA. Kemudian disusul oleh mereka yang memiliki pendidikan SMP \& S1, yaitu sebesar 12 responden atau 15,0 persen. Terakhir responden yang berpendidikan SD sebanyak 3 orang atau 3,8 persen. Hal ini menunjukkan bahwa sebagian besar responden telah menamatkan program wajib belajar 12 tahun. Responden adalah para wirausahawan yang menggeluti bidang peternakan. Hal ini menunjukkan bahwa UPTD Puskeswan benar-benar dimanfaatkan oleh para peternak dan pengusaha peternakan yang ada di Kab. Purbalingga. Pengguna layanan UPTD Puskeswan di Kab. Purbalingga baru sebatas memanfaatkan layanan pemeriksaan kesehatan hewan. Mayoritas jawaban responden pada masing-masing unsur pelayanan masuk kategori baik, namun unsur biaya dan penanganan pengaduan mayoritas jawaban responden masuk kategori sangat baik. Dari seluruh responden, tidak ada yang memberikan jawaban pada kategori tidak baik.

Korelasi tertinggi dengan nilai 0,602 berada pada tingkat hubungan yang kuat yakni antara unsur perilaku pelaksana dan unsur Produk layanan. Kedua unsur tersebut berkorelasi secara positif dan signifikan. Hal ini menunjukkan adanya keterkaitan yang sangat kuat antara kualitas perilaku pelaksana dengan kualitas produk layanan, yakni semakin baik perilaku pelaksana maka akan semakin baik produk layanannya. Temuan yang menarik dari hasil survei ini adalah adanya korelasi secara negatif dan signifikan antara unsur sarana prasarana terhadap unsur penanganan pengaduan. Hal ini menunjukkan sebuah pola hubungan yang saling bertolak belakang, yakni semakin baik unsur sarana prasarananya akan semakin buruk 
nilai pengaduannya (tidak ada pengaduan), begitu juga sebaliknya apabila unsur sarana prasaranya tidak baik maka unsur pengaduannya akan semakin baik (banyaknya pengaduan dengan respon yang baik dari pihak Puskeswan).

Berdasarkan tabel SKM, dapat diketahui bahwa nilai Kinerja UPTD Puskeswan tahun 2017 memperoleh nilai Baik (B) dengan angka 77,60. Dari seluruh unsur pelayanan, nilai tertinggi terpadat pada unsur biaya $(99,69)$, sedangkan nilai terendah terdapat pada unsur Penanganan Pengaduan $(62,81)$.

\section{KESIMPULAN}

Secara umum, unsur yang paling banyak memperoleh nilai tinggi adalah unsur kepastian biaya pelayanan; sementara yang memperoleh nilai paling rendah adalah fasilitas layanan. Sementara itu, Indeks Kepuasan Masyarakat (IKM) secara umum di 7 instansi unit pelayanan masuk kategori B, artinya, beberapa instansi tersebut dianggap telah memberikan pelayanan masyarakat secara baik. Setiap unusur pelayanan berkorelasi terhadap unsur pelayanan yang lain. Dari berbagai korelasi yang ada, unsur Perilaku Pelaksana berkorelasi secara signifkan terhadap setiap unsur pelayanan lainnya. Pengguna layanan publik mayoritas merupakan penduduk usia produktif antara 26-46 Tahun. Berdasarkan tujuh instansi yang disurvei, hanya satu instansi yang ditemukan memiliki IKM dengan Kategori C yaitu Dinas Penanaman Modal dan Pelayanan Terpadu Satu Pintu (DPMPTSP). Sementara itu, Dinas Arsip dan Perpustakaan, Dinas Tenaga Kerja, Kecamatan Mrebet, RSUD dr.Goeteng T., UPTD Puskesmas Mrebet dan UPTD Puskeswan masing masing memiliki IKM dengan Kategori B.

Rencana tindak lanjut perbaikan untuk meningkatkan kepuasan masyarakat pengguna layanan diantaranya prioritas unsur persyaratan pada program/ kegiatan deregulasi persyaratan pelayanan dalam waktu jangka menengah yaitu adanya evaluasi dan penyederhanaan persyaratan pelayanan sedangkan untuk jangka panjangnya berupa digitalisasi persyaratan layanan. Adapun penanggung jawabnya berasal dari semua unit layanan (utamanya layanan perijinan). Kemudian prioritas unsur prosedur untuk program/ kegiatan pelayanan publik pro lansia dalam waktu jangka pendek adalah prioritas pada lansia dengan penanggung jawab dari Unit Layanan Kesehatan. Selanjutnya, prioritas unsur waktu pelayanan untuk program/ kegiatan pengelolaan waktu kunjungan / pelayanan dalam jangka pendek yakni penjadwalan kunjungan dokter hewan, sedangkan jangka panjangnya berupa pemanfaatan teknologi informasi dalam penjadwalan kunjungan. Penanggung jawab hal ini berasal dari Puskeswan.

Rencana tindak lanjut lainnya dalam perbaikan peningkatan kepuasan masyarakat pengguna layanan meliputi prioritas unsur produk layanan untuk program/ kegiatan pengembangan produk layanan dalam waktu jangka pendek yaitu penambahan vaksin dan penanganan penyakit serta penambahan referensi buku. Adapun unit yang bertanggung jawab 
adalah puskeswan dan perpustakaan. Selanjutnya, prioritas unsur penanganan pengaduan, saran dan masukan untuk program/ kegiatan optimalisasi fungsi pengaduan masyarakat dalam jangka pendek adalah sosialisasi penanganan pengaduan. Seluruh unit pelayanan bertanggung jawab hal ini. Kemudian, prioritas unsur sarana dan prasarana pada program/ kegiatan pemenuhan kebutuhan dalam sarana prasarana dalam jangka menengah meliputi peningkatan kapasitas dan fasilitas ruang tunggu serta melengkapi sarpras penunjang pelayanan. Penanggung jawab untuk urusan ini meliputi seluruh unit pelayanan.

\section{DAFTAR PUSTAKA}

Hardiyansyah. 2011. Kualitas Pelayanan Publik Konsep, Dimensi, Indikator, dan Implemtasinya. Yogyakarta: Gava Media.

Kabupaten Purbalingga Dalam Angka Tahun 2017. Badan Pusat Statistik Kabupaten Purbalingga.

Laporan Masyarakat oleh Ombudsman Republik Indonesia Tahun 2017.

Peraturan Menteri Pendayagunaan Aparatur Negara dan Reformasi Birokrasi Republik Indonesia Nomor 14 Tahun 2017 tentang Pedoman Penyusunan Survei Kepuasan Masyarakat (SKM) Unit Penyelenggara Pelayanan Publik.

Purnama, Nursya'bani. 2006, Manajemen Kualitas: Perspektif Global, Ekonisia, Yogyakarta. 